\title{
Commitment, Communication, and Leadership Determine the Leader: A Qualitative Analysis of Businessperson Characteristics Practiced by SME and Family Business Directors
}

\author{
Olga V. Missioura \\ Nyenrode Business University, Breukelen, The Netherlands
}

\begin{abstract}
This article outlines the details of an empirical study into the perceptions of small and medium-sized enterprise (SME) directors regarding the concepts of communication and commitment to leadership style and the interpretation of these concepts by way of depth interviews. The commitment by SME directors is represented by the themes of emotional commitment, visibility, financial bond, and personality traits. The communication by SME directors is represented by the themes of empathy, type of information, reaction and personality of the communication. The concept of leadership in the SME sector is typically closely associated to the charismatic leadership and the theory of the inclusive leadership (IL) style. The IL is a representation and use of all of the represented leadership styles depends on a situation. This study can be described as an exploratory study, consisting of qualitative in-depth interviews that were conducted with 19 directors of SMEs in the Netherlands and a qualitative matrix method was utilised.
\end{abstract}

Keywords: commitment, communication, leadership style, leadership in the SME sector, businessperson characteristic, family business, business performance, behaviour

\section{Introduction in Behavioral Aspects of the Leader}

Leaders in the SME sector are creators of social and economic values of their companies and the environment they are operating in. Their goals and ambitions can lead the companies to high performance and a resilient and sustainable enterprise. The expectations about the not optimal or very good performance of the company can be explained by the behaviour of SME directors and the "businessperson characteristics" of SME director. The performance determinants are the results and the efficiency and effectiveness of the company activities. The company activities (to communicate, to control, to identify the risks, to take/get responsibility - internal control) are determined and organized by the director/leader of the company. If the company activities are not very well organised, it leads to poor performance. For this reason it is very important first to understand the concept of the leader ("businessperson characteristics") before to explain the behaviour and the performance of the companies.

Olga V. Missioura, MA/LLM, Accounting \& Controlling Department, Nyenrode Business University.

Correspondence concerning this article should be addressed to Olga V. Missioura, Straatweg 25, 3621MS, Breukelen, The Netherlands.E-mail: o.missioura@nyenrode.nl; ovmissioura@gmail.com. 
The supportive behavior of the leader influence the problem-solving capacity of employees, especially creative performance and originality (Carmelin, 2013). Coulson-Thomas introduces "new leadership" concept for multiple benefits and more affordable route to the high performance, because "traditional leadership is not working" (Coulson-Thomas, 2013). Entrepreneurial leadership style is very effective for increasing financial performance in SME sector (Sam, 2012). The creative performance, as one of the important path to organizational performance, is influenced by authentic leadership (Rego, Sousa, Marques, \& Pina e Cunha, 2014). Another study provides a model explaining the process through which transformational leadership influences creative behavior and organizational citizenship behaviors (Tse \& Chiu, 2014).

The study of this paper regarding the concept "businessperson characteristics" tested the interpretation of the selected concepts in a conceptual model for leaders within the SME sector. This study provides more knowledge and insights to the clarity regarding the interpretation of the concepts of "businessperson characteristics", namely, commitment and leadership. By way of this study, the results regarding the method behind the interpretation of "businessperson characteristics", show the SME directors characteristics. On the basis of a qualitative analysis, a review was conducted of the input concepts that was considered to be the most desirable and was therefore utilised by the SME directors. The answers have been subdivided into themes for each concept (communication, leadership, and commitment) and the distribution pattern has been incorporated in different Tables (see Tables 4, 6, 7, and 10). The main question posed in my study is as follows:

- How does the concept "businessperson characteristics" in interaction with the process of behaviour (attitude, beliefs, etc.) and internal control system of the company influence the performance determinants of the company?

The research subject of this paper is understanding and recognizing of the determinants of the concept "businessperson characteristics" in SME sector, by way of discussing of three concepts: commitment, communication, and leadership. Hereafter is the next step-instrument developing for the different leader determinants based on original/first data from the author's survey questionnaire. The main question posed only in this paper is:

- In which manner is the concept "businessperson characteristics" interpreted and utilised by the businessperson/director in SME?

The research purpose of this paper helps in understanding of the nature of the leader/entrepreneur in SME sector and family business. This study provides knowledge of and insight into the manner in which the concept of "businessperson characteristics" is interpreted within the SME sector by the directors themselves and determines the new elements to the scarce literature available regarding the subject of the SME director in the Netherlands.

In chapters "Literature About the Leadership", "The Definition of Commitment", "The Definition of Communication", "The Definition of Leadership" of this article, the first aspects relate to the definition of the concepts of leadership, commitment, and communication are discussed. Subsequently, in chapter "Methodology", the results of exploratory studies relating to the interpretation of each concept have been presented in a matrix analysis. The results of the exploratory research and the results of the study have been incorporated in Tables 4, 6, 7, and 10 and additional explanations have been included. Chapter "Conclusions" completes this article with the final conclusions and further discussion. 


\section{Literature About the Leadership}

The entrepreneur/leader of the company is "the economic operator, that as a leader, the company makes decisions about an uncertain future and has responsibility for its survival”, the person with risk behavior and which has the following characteristics: assessing the uncertainties, taking initiative, the continuation of its reassessment of the performance of others (van der Valk, 1950). The business culture in SME sector in the Netherlands (enterprises with 10 to 250 employees) is the family culture: $47 \%$ of the cases (Koning, 2013). Ouchi (1979) talks about the clan mechanisms-flexible, intern oriented, informal culture with behaviour of collaboration, or with other words-family culture. The leaders of the companies can influence and optimise the organisational culture (Haneberg, 2009). Another study illustrates that "human resource management practices is an important ancestor of organisational culture... which has in turn a positive link to organisational performance" (Al-bahussin \& El-garaihy, 2013). The leadership fosters employee commitment and brand supporting behaviors of employee in a company (Wallage, De Chernatony, \& Buil, 2013a).

The leader of the company is in state of being bound to the company-financially, emotionally, by family obligations, or with other words - it is going about the involvement/commitment of the leader. The job involvement is positively related to job performance and "this implies that creating sufficient interest in the job objectively involves an individual to his/her responsibilities and this reflects on augmented performance levels" (Soumendu, 2011). Affective commitment and normative commitment were strong predictors of organisational citizenship behaviours in Turkish SME's (Uçanok \& Karabat1, 2013). The leader of the company is connected to the company by way of an engagement by contract involving obligations and by way of feeling of other needs, who leads, takes the decisions, communicates and informs about. The use of communication and change management leads to sustainable performance and "it mentions that employees at high performance companies looked for leader's characteristics" and also notes the role of communication for leaders to create clarity, deliver confidence, and build community (Wallage et al., 2013b). The leader is the one who leads and directs, the one who has the authority, the one whose qualities, roles, and leadership style, together with initiative and responsibility, leads the organisation in a particular direction by way of his/her leadership. Directive leadership enhanced proactive behaviors for work units that were highly satisfied with their leaders, whereas empowering leadership had stronger effects on both core task proficiency and proactive behaviors for work units (Martin, Liao, \& Campbell, 2013).

The quality of the leader and the results of their behaviors can be interpreted by way of understanding of three concepts: commitment, communication, and leadership. It can be stated that the need for empirical testing of complete profile (businessperson characteristics) of the leader in SME and influence on behavior and performance is significantly noticed. Also, it motivates this research to develop and identify the clear dimension and future measurement of behavior determinants in SME sector. First the study explained the three definitions of commitment, communication, and leadership (Missioura, 2013a). Then, the study showed the choice of the directors in SME sector (19 depth interviews) for "businessperson characteristics" concepts and discuss the original results of the presented data by used concepts (commitment/involvement, communication, and leadership) deficit implies that decision makers systematically overestimate their capacity to reach stated goals. 


\section{The Definition of Commitment}

There are a variety of meanings about the commitment. Commitment or involvement is linked to togetherness and connectedness through an emotional bond or obligations. Commitment in organizations is going about the feeling of the responsibility, engagement or positive orientation of the person to the organization/target/work etc.. The commitment of the leader to the company is going through an emotional bond or obligations. Etzioni (1964) spoke about "...the typical orientation of the group of participants one observes has tot be established. How alienated or committed are they?". Allen and Meyer (1991) introduced a three-component conceptualization of organizational commitment: a desire (affective commitment), a need (continuance commitment), and an obligation (normative commitment).

Etzioni (1964) introduced the commitment as a relationship of the participants to the place in their organisations. Etzioni (1964) spoke about “...the typical orientation of the group of participants one observes has tot be established. How alienated or committed are they?". Etzioni (1993) introduced the commitment as a determinant to govern individual choices through the infusion of normative influence. There are two parts in the definition of commitment: normative commitments and affective involvements. It is going by loading of personal priorities and intrusion on the linear sequencing of personal decision making (Etzioni, 1993). The commitment is going about the "affective attachment to the goals and values, and to the organization for its own sake, apart from its purely instrumental worth" (Buchanan, 1974). Organizational commitment is defined as the desire to remain a member of an organization, to exert high levels of effort for the organization, and to accept the organization's beliefs (Hoell, 2004). Wiener (1982) spoke about "the totality of internalized normative pressures to act in a way which meets organizational goals and interests", by the way of believing — it is right/moral thing to do. The commitment of employee considers it morally right to stay in the company, regardless of how much status enhancement or satisfaction the firm gives to him over the years (March \& Mannari, 1977).

Allen and Meyer (1991) introduced a three-component conceptualization of organizational commitment: a desire (affective commitment), a need (continuance commitment), and an obligation (normative commitment). With regard to commitment in its various forms, the three recent aspects of commitment are selected:

- an obligation (Etzioni, 1964, 1993; Allen \& Meijer, 1991, 1996);

- a feeling (emotional/affective aspect) (Buchanan, 1974; Allen \& Meijer, 1991, 1996; Etzioni, 1993);

- a profitability (needs/costs) (Allen \& Meijer, 1991, 1996; Kibeom, Allen, \& Meijer, 2001).

Attitudinal commitment focuses on the process by which people come to think about their relationship with the organization. (...) Behavioral commitment relates to the process by which individuals become locked into a certain organization and how they deal with this problem. (Mowday, Porter, \& Steers, 1982, p. 26)

Leadership commitment influences the employee health and work ability and contributes to quality management in the companies (Lagrosen, Bäckström, \& Wiklund, 2012). The lack of commitment may lead to failure in an organization and has an impact on employees and external environment of organizations operating in.

\section{The Definition of Communication}

Communication is the negotiation, opportunity for exchanging of ideas, intellectual ability for consultation, spiritual talent to verbal or nonverbal communicate to provide specific information to another person or group. 
Garcia (2012) defined the communication as "an act of the will directed toward a living entity that reacts". "If you want to know why so many organizations sink into chaos, look no further than their leaders' mouth". (Hamm, 2006). The leaders present grand, (...) notions of where they think the company is going, (...) assume everyone shares their definitions of "vision", "accountability", and "results", even it is not the case and leader misalignment with the sloppy behaviour of employers can cost a company dearly. That is the reason why effective communication is the leader's most critical and essential job tool of leadership (Hamm, 2006).

Transparent communication helps the leaders increase self-awareness and responsibility in themes of honesty/integrity, life balance, and relationships (Remund, 2011). Maximal goal communication is more effective and persuasive when leaders show the enthusiasm and openness (Venus, Stam, \& Van Knippenberg, 2013). Precise and transparent communication of the leaders, the clear reports to other managers, who communicates also with equal precision to their employees, aligns the organization's commitment and energy with a well-understood vision of the firm's real goals and opportunities (Hamm, 2006). There is relationship among communication and enthusiasts in organizations in four factors, namely, the rhetoric courage, extreme form of motivation and commitment. Communication is one of the most important competencies of the leadership skills (Sinar, 2013). Communication is also related to the personality trait such as extrovert or introvert person that express the person's degree of willingness to communicate (Caligiuri \& Tarique, 2009). Goldberg (1992) emphasized a positive and negative poll of extraversion as follow in Table 1.

Table 1

Goldberg Scale of Extraversion

\begin{tabular}{|l|l|}
\hline Negative scale & Positive scale \\
\hline Introverted & Extraverted \\
\hline Unenergetic & Energetic \\
\hline Silent & Talkative \\
\hline Unenthusiastic & Enthusiastic \\
\hline Timid & Bold \\
\hline Inactive & Active \\
\hline Inhibited & Spontaneous \\
\hline Unassertive & Assertive \\
\hline Unadventurous & Adventurous \\
\hline Unsociable & Sociable \\
\hline
\end{tabular}

Notes. See also for personality traits and extraversion. Source: Felf \& Schyns (2006) and Moss Simon \& Ngu (2006).

There is interlink between personality traits and communication because the personal dimension as extraversion and conscientiousness determine the communicative behaviour of the leaders (Bakker-Pieper \& Vries, 2013). Communication is one of the most important competencies of the leadership skills and it gives different opportunities to achieve their own and company goals.

\section{The Definition of the Leadership}

The leader is the one who leads and directs, the one who has the authority, whose qualities, roles, and leadership style, together with initiative and responsibility, leads the organisation in a particular direction.

Leadership refers to the personality of the leader, the characteristics and the qualities held by the individuals to 
influence others and to make every effort to contribute to achieving the objectives for the success of the department or organisation where they work. (Van Muijen, 2003)

"Leadership with significant ownership in a company/leadership by management with significant ownership interest or rights" is one of the characteristics of an enterprise (COSO, 2006).

In relevant literature, there are two main schools of thought that can be distinguished with regard to leadership:

- The charismatic/value-based theory is developed by Conger (1989) that is based on the perception of the behaviour of the leader by his/her followers, with divisions in transformational, transactional and laissez-faire leadership (Weber, 1947; Conger, 1989; Conger \& Kanungo, 1987, 1988, 1992 1994; Conger, Kanungo, \& Menon, 2000; Conger, Kanungo, Menon, \& Mathur, 2009).

- The full range theory utlines three types of leadership, varying from passive to active leadership styles, with divisions in charismatic, transactional, autocratic, and laissez-faire leadership (Burns, 1978; House, 1977; Cardona, 2000; Ehrhart \& Klein, 2001).

The concept of leadership style is a complex concept and the stated definitions of leadership style include multiple aspects and dimensions (completed study/publication about the leadership - inclusive leadership (IL) in the small to medium sized enterprise sector) (Missioura, 2013a). From the author earlier study (Missioura, 2013a) it showed uses of leadership styles in the practise of SME directors: "IL in the SME sector is situational leadership that is dependent upon the context and the needs of the followers in accordance with the context and results, for the highest levels of efficacy and efficiency" and the effective leadership is not a representation of a particular one type of leadership (hierarchical, delegation, participative, closed), but uses of all of the represented leadership styles depend on situation.

The choice of 19 SME directors, by way of building of the conceptual model in the author previous study differs from the choice of professionals (scientists) (Missioura, 2013b), and is more close and important for the practice of SME companies in the Netherlands. For this reason the author choose to explain the results of three concepts (leadership, communcation, and commitment/involvement) as the base for behaviour of the leader of company.

In the next chapter the methodology and results of all concepts have been separately presented.

\section{Methodology}

The conceptual model was established on the basis of the COSO framework and the Theory of Reasoned Action (TRA) model developed by Fishbein \& Aijzen (1975) and it illustrates the structure and level of detail of the internal control measures selected by the chief executive officer (CEO) or the chief financial officer (CFO). The analysis of the results of the interviews, together with the theoretical framework of the Fishbein \& Aijzen (1975) model and components of the COSO Internal Control-Integrated Framework (ICIF, 1992) led to the drafting of the questions for the survey research for this component.

The conceptual model consists of four components, as follows:

- Basic/Input concepts (characteristics of the enterprise/businessperson);

- Psychological/Mental (Fishbein \& Aijzen, TRA model concepts);

- Behaviour/Business activities (investment behaviour and COSO 1992 components);

- Yields/Revenues (efficiency/effectiveness and satisfaction).

The complete conceptual model has been visually incorporated in Figure 1. 


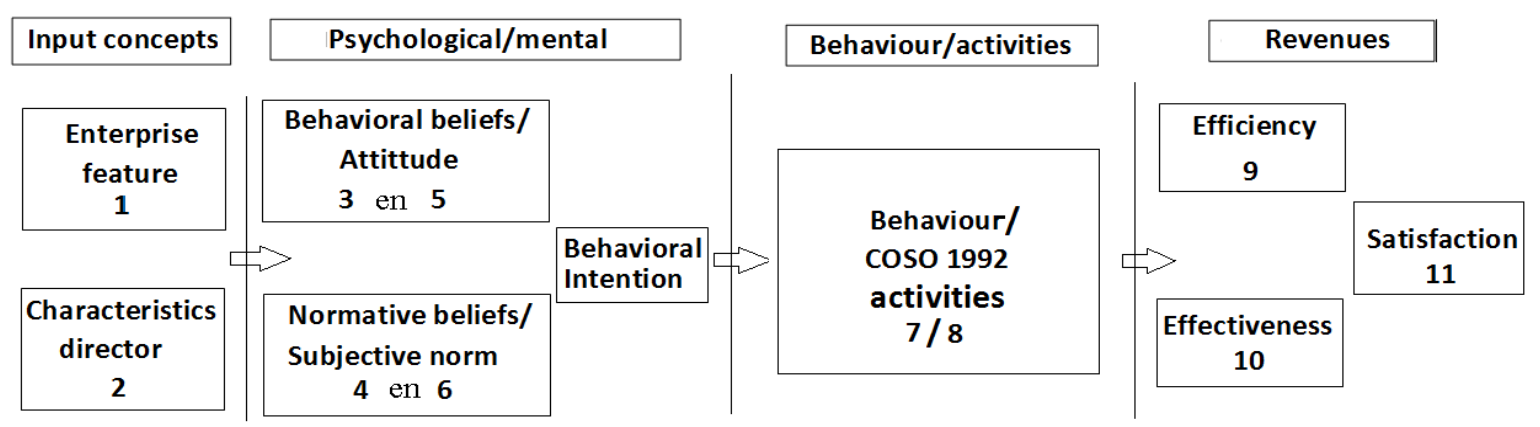

Figure 1. The complete conceptual model.

The research method included conducting in-depth interviews with 19 SME directors, whereby they were asked to provide additional details and interpretation regarding the concepts from the conceptual model, to select the most important concepts from the conceptual model and to indicate the causal relationships between the concepts by drawing directional arrows (Missioura, 2013b).

This article outlined the interpretation of the "businessperson characteristics" by SME directors and discuss the represented input concepts from the conceptual model- "characteristics director" (commitment, communication, and leadership, see Figure 2).

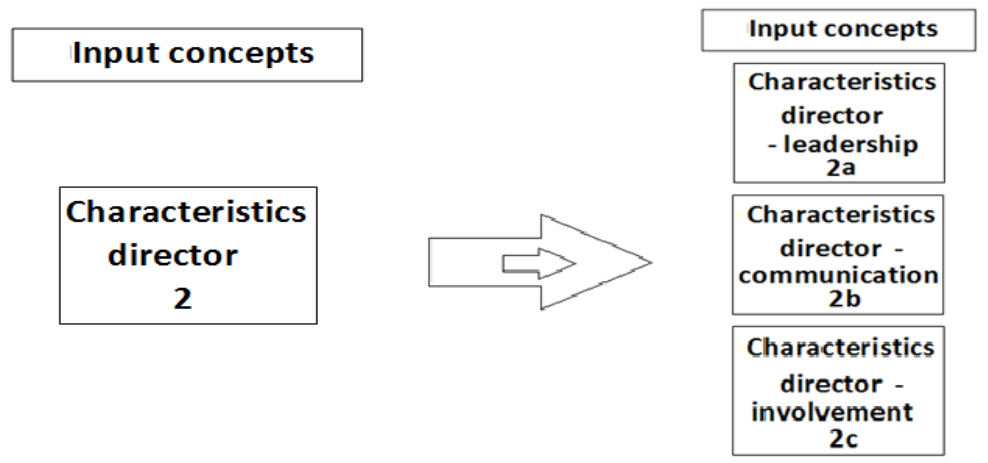

Figure 2. The input concepts from the conceptual model discussed in the paper.

Sample SME directors: Below, the characteristics of the directors interviewed have been incorporated into Table 1.

Table 1

Characteristics of the Directors in the Qualitative Study

\begin{tabular}{llllr}
\hline & D/MS & CFO & CEO & Total \\
\hline Male & 4 & 5 & 3 & 12 \\
Female & 2 & 2 & 2 & 6 \\
Total & 6 & 7 & 5 & 18 \\
\hline
\end{tabular}

Table 1 explanation: In total, 18 SME directors were interviewed, of whom 12 participants were males and six participants were females. In the group, directors/major shareholders, a total of six participants were interviewed, i.e., four males and two females. In the group, CFO's, a total of seven participants were interviewed, i.e., five males and two females. In the group, CEO's, a total of five participants were interviewed, i.e., three males and two females.

In the next chapter the results of concept of commitment have been separately presented. 


\section{Commitment—Study Results}

Below, the questions that were posed in the study have been incorporated into Table 2 - commitment study questions.

Table 2

Commitment Study Questions

\begin{tabular}{|l|l|l|}
\hline Study question & Concept & Interview question \\
\hline $\begin{array}{l}\text { In which way is the concept of "businessperson } \\
\text { characteristics" interpreted and detailed by the } \\
\text { businessperson/director? }\end{array}$ & Concept-commitment & $\begin{array}{l}\text { Which commitment/involvement elements } \\
\text { can you list for a director (in general)? }\end{array}$ \\
\hline
\end{tabular}

On the basis of the responses from the SME directors to the question posed regarding the commitment elements that they could list and explain (general), it was possible to distinguish four separate communication themes:

Theme 1: Emotional commitment - the state of being emotional/affective bound to the organization.

Theme 2: Visibility_presence of the director in organization in various ways: personal, internal/external communication.

Theme 3: Financial bond/connection_financial aspects, ownership, shareholder, salary, and bonus.

Theme 4: Personality traits-combination characteristics or objective features of the person (director/CEO/CFO), for example, age, experience, knowledge, training, health, etc..

The different responses of the respondents explaining about the various aspects of commitment have been incorporated into Table 3.

Table 3

Themes Involvement/Commitment (General)

\begin{tabular}{|c|c|c|c|}
\hline Subjective elements of the commitment & \multicolumn{3}{|c|}{ Objective elements of the commitment } \\
\hline Emotional commitment & Visibility & Financial bond & Personality traits \\
\hline $\begin{array}{l}\text { - my involvement is extremely/very } \\
\text { large } \\
\text { - the company like } \\
\text { - own family feeling } \\
\text { - feeling at the company have } \\
\text { - are afflicted } \\
\text { - feel and see if its place } \\
\text { - own enthusiasm } \\
\text { - proud, to feel/to be } \\
\text { - responsibility feeling }\end{array}$ & $\begin{array}{l}\text { - regular presence } \\
\text { - not only contract } \\
\text { director } \\
\text { - communicate with } \\
\text { people: how it is going? } \\
\text { - director on the paper } \\
\text { - to be as an exam-ple for } \\
\text { the people in the organization }\end{array}$ & $\begin{array}{l}\text { - shares } \\
\text { - salary } \\
\text { - bonus } \\
\text { - variable financial } \\
\text { bonus } \\
\text { - rate of return/ profit } \\
\text { - payment } \\
\text { terms/conditions }\end{array}$ & $\begin{array}{l}\text { - Knowledge (market, } \\
\text { industry, customers, } \\
\text { - experience } \\
\text { - age } \\
\text { - health } \\
\text { - talent/business skills } \\
\text { - spiritual maturity }\end{array}$ \\
\hline
\end{tabular}

Based on Table 3, it is apparent that the first group "emotional commitment" relates to a subjective element and the three other groups, "visibility", "financial bond", and "personality traits" relate to an objective elements of the commitment. The subjective elements of the commitment are feelings and perceptions of the person for the company. For example, to be proud of the company, product, services, tasks, and responsibility:

- "When people asking me: what are you doing? And I have a good story about the business, my own commitment and our quality, skills, input in our business, it is going to be better together with the company";

- "Passion for the company, just to be proud for the product, services, to be concerned with your own people, sociable and friendly for the company";

- "A director who convinces and works with the heart and drive for the company, who knows what is 
important we are doing";

- "If you are going to change our mission and vision I'm just going to lose my involvement".

Table 4

Involving Elements of SME Director

\begin{tabular}{|l|l|l|}
\hline Subjective elements of the commitment & Objective elements of the commitment \\
\hline
\end{tabular}

\begin{tabular}{|l|l|l|l}
\hline Emotional commitment & Visibility & Financial bond & Personality traits
\end{tabular}

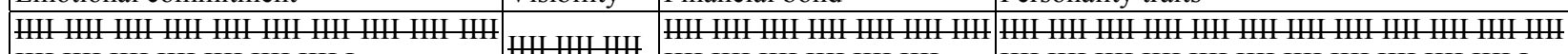

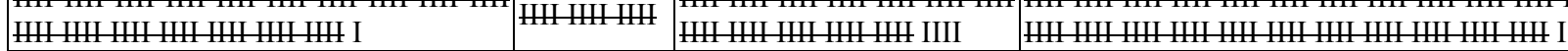

Notes. HII: the number of answers occurring five times; I: the number of answers occurring one time.

The distribution patterns of the participants in Table 4 (directors of SME's/family businesses) revealed a dominant pattern in three types of commitment elements (one subjective and two objective elements of the commitment), i.e., emotional commitment and personality traits, and a financial bond with the company. A lower distribution pattern was revealed in terms of the visibility in the company (objective element of the commitment).

The emotional commitment, or with other words the sense of involvement with the company:

- "I get a lot of the energy in the company, I like to work here";

- "It is very enjoyable to speak with the customers, to ask about their needs, to help them";

- "My contribution to our vision just goes to build together the happiness in the company";

- "I am very involved to my company".

Personality traits: work experience, age, health, seniority and maturity, and dominance.

Financial aspects:

- "I just get my salary and my bonus-it is another bond, a connection to the company";

- "There is also a variable and a fixed component of the salary, plus the bonus, yes";

- "You just get the salary and another component is dependent on the profit". Visibility:

- "You are doing a lot with the company, you are connected, not only financially, but also your own presence, by yourselves in the company and (...) by external contacts, (...), with internal contacts also";

- "Every day busy for the company, (...) from the morning 9:00 am to the evening 9:00 pm";

- "I have 30 meetings a week, it is about two or three times in year";

- "I know everything about a company, I ask every day people, I say — good morning and this and this and this, (..), I am very concerned, I actually know everything, everything plays in the company".

In the next chapter the results of concept of communication have been separately presented.

\section{Communication-Study Results}

Below, the questions that were posed in the study have been incorporated into Table 5 .

Table 5

Communication Study Questions

\begin{tabular}{|l|l|l|}
\hline Study question & Concept & Interview question \\
\hline $\begin{array}{l}\text { In which way is the concept of "businessperson characteristics" } \\
\text { interpreted and detailed by the businessperson/director? }\end{array}$ & Concept-communication & $\begin{array}{l}\text { Which communication/elements can } \\
\text { you list for a director (in general)? }\end{array}$ \\
\hline
\end{tabular}

On the basis of the responses from the SME directors to the question posed regarding the types of communication that they could list and explain (general), it was possible to distinguish four separate communication themes: 
Theme 1: Empathy_-identification with and understanding of another's situation, feelings, and motives;

Theme 2: Type of information - a special collection of facts or data for specific target group (e.g., mail message, speech, motivational/convincing story);

Theme 3: Reaction/response - communicative response or action to a stimulus/important event from out or inside of the organization;

Theme 4: Personality — combination of qualities or features of the person (director/CEO/CFO), image, for example, powerful leader, hierarchical/quirky/compassionate person.

Table 6

Communication Elements in the SME

\begin{tabular}{|l|l|l|l|l|}
\hline & Empathy & Type of information & Reaction & Personality \\
\hline Total & III I & IIII IIII IIII IIII IIII IIII IIII IIII IIII IIII IIII IIII & IIII IIII II & IIII IIII IIII IIII II \\
\hline
\end{tabular}

Notes. IIII: the number of answers occurring five times; IIII: the number of answers occurring four times; and II: the number of answers occurring two times.

The participants listed and detailed the various communication elements (see Table 6). On the basis of the answers from the participants, a division was made into four different communication elements. In Table 7, the subjects/synonyms associated with these four themes have been incorporated per average of communication by women/men. On this basis hereof, it is possible to identify the dominant distribution pattern from the aspects of communication elements that are used in directing and communicating with the employees in the enterprise.

Table 7

Communicatiom-Woman/Man Average

\begin{tabular}{|l|l|l|l|l|}
\hline & Empathy & Type of information & Reaction & Personality \\
\hline Average women & HI I & III & HI III & IH I \\
\hline Average men & II & IIII & HII I & 世IIIII III \\
\hline
\end{tabular}

Notes. IIII: the number of answers occurring five times; IIII: the number of answers occurring four times; III: the number of answers occurring three times; and I: the number of answers occurring one time.

The distribution patterns of the participants in Table 7 (directors of SME's/family businesses) in communication elements revealed a dominant pattern in two main elements:

- Empathy, the listening and understanding of another person is higher represented by female respondents;

- Personality of the director in communication is more important for male respondents than female respondents.

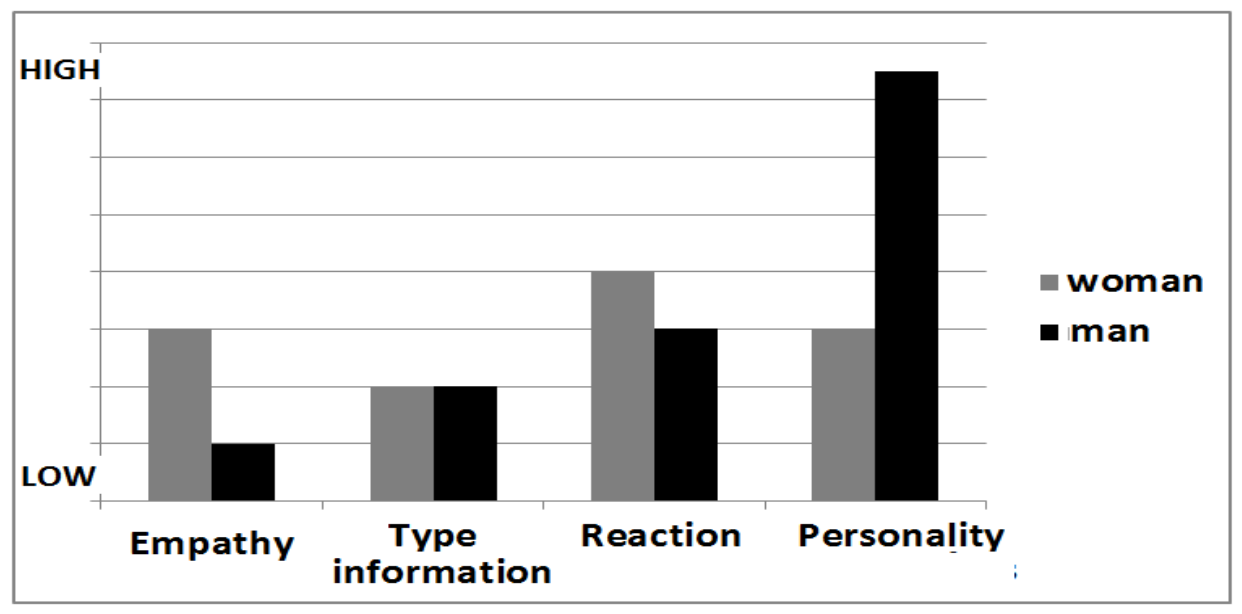

Figure 3. Average communication elements man/woman. 
The average of the choice of the type of information is the same in both groups. The average of the reaction to important events from outside or inside the organization is a little bit higher by women than by men (see Figure 3).

In the next chapter the results of concept of leadership have been separately presented.

\section{Leadership—Study Results}

The research method included conducting in-depth interviews with 19 SME directors, whereby they were asked to provide additional details regarding the concepts from the conceptual model, to select the most important concepts from the conceptual model and to indicate the causal relationships between the concepts by drawing directional arrows. Below, the questions that were posed in the study have been incorporated into Table 8 .

Table 8

Leadership Study Questions

\begin{tabular}{|l|l|l|}
\hline Study question & Concept & Interview question \\
\hline $\begin{array}{l}\text { In which way is the concept of "businessperson characteristics" } \\
\text { interpreted and detailed by the businessperson/director? }\end{array}$ & Concept—leadership & $\begin{array}{l}\text { Which leadership styles can you list for } \\
\text { a director (in general)? }\end{array}$ \\
\hline
\end{tabular}

On the basis of the responses from the SME directors to the question posed regarding the types of leadership that they could list and explain, it was possible to distinguish four separate themes (i.e., hierarchical, delegational, participative, and closed):

Theme 1: Hierarchical/authoritarian leadership-communicating via different layers in the organisation - directive, imposing, domineering;

Theme 2: Delegational—allocating responsibilities;

Theme 3: Participative/polder model—open communication, leaders who motivate and communicate - direct, flat leadership;

Theme 4: Closed—non-communicative/unclear.

The participants listed and detailed the various leadership styles. On the basis of the answers from the participants, a division was made into four different leadership styles. In Table 9, the subjects/synonyms associated with these four themes have been incorporated per leadership style. On this basis hereof, it is possible to identify the aspects of each leadership style that are used in directing and communicating with the employees in the enterprise.

Table 9

Leadership Style Subjects

\begin{tabular}{|c|c|c|c|}
\hline Hierarchical & Delegational & Participative & Closed \\
\hline \begin{tabular}{|l} 
- authoritarian leader \\
- bureaucratic \\
- vertical style \\
leadership \\
- imposing, formal \\
- dictating \\
- controlling \\
- demanding \\
- insisting \\
\end{tabular} & of $\begin{array}{l}\bullet \text { delegational } \\
\text { to allocates responsibilities } \\
\text { - throws people into the } \\
\text { deep } \\
\text { - invisible management } \\
\text { - check and release }\end{array}$ & $\begin{array}{l}\text { - Consultative } \\
\text { - Horizontal style of } \\
\text { leadership } \\
\text { - Serve } \\
\text { - Participative } \\
\text { - Inspiring } \\
\text { - Coaching, high degree of } \\
\text { freedom } \\
\text { - People-orientated }\end{array}$ & $\begin{array}{l}\text { - Unclear } \\
\text { - Undermines people } \\
\text { - Non-communicative } \\
\text { - All-knowing } \\
\text { - Silent } \\
\text { - Closed }\end{array}$ \\
\hline
\end{tabular}

Based on Table 9, it is apparent that the first two groups of subjects (hierarchical and delegational) relate 
to a style of leadership whereby distance is created between the leader and others.

The other two groups (participative and closed) appear to lean more towards communicating with the person who is also a part of the organisation. For example,

Look, I so often see people in business who very quickly make it easy for themselves. They sit very comfortably in a chair, hand out particular responsibilities and run many companies. Then this is the workplace and ultimately, the management teams are located on the other side of the city. (source: depth interview with SME director)

In relation to the question regarding the types of leadership styles, the participants made a clear distinction between either hierarchical/aloof, or delegational/human. Subsequently, the subjects were also listed regarding the manner of communication of a leader and if this was open communication, or if there was minimal communication in the company. The participants also considered it important to be able to combine leadership styles, regardless of their own leadership styles, depending upon the situation.

Table 10

Businessperson Leadership Style Subjects

\begin{tabular}{|c|c|c|c|c|c|}
\hline & $\begin{array}{l}\text { Authoritarian/hierarchical } \\
1\end{array}$ & $\begin{array}{l}\text { Delegational } \\
2\end{array}$ & $\begin{array}{l}\text { Communicative/participative/polder } \\
\text { communication } \\
3\end{array}$ & $\begin{array}{l}\text { Non-communicative/unclear } \\
4\end{array}$ & $\begin{array}{l}\text { Combined } \\
\text { leadership } \\
\text { styles } \\
5\end{array}$ \\
\hline Total & 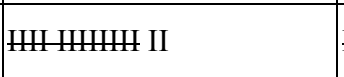 & HIIIIII & 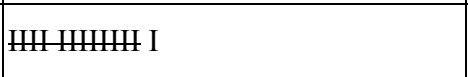 & II & $\begin{array}{|ll|}\mathrm{HI} & \text { НHНH } \\
\mathrm{III} & \\
\end{array}$ \\
\hline
\end{tabular}

Notes. Ш世Щ世: the number of answers occurring 10 times; HI: the number of answers occurring five times; IIII: the number of answers occurring four times; III: the number of answers occurring three times; II: the number of answers occurring two times; and I: the number of answers occurring one time.

The distribution patterns of the participants (directors of SME's/family businesses) revealed a dominant pattern in two types of leadership style, i.e., authoritarian and communicative, a flat, accessible manner of leadership. The distribution pattern was very weak in relation to non-communicative/aloof and unclear types of leadership and these were uncommon and not typical amongst the total population of directors in the SME sector. From the quotes above, it would appear that the interpretation of ideal leadership depends on the situational and contextual aspects and on the basis thereof, the leader must select a passive/directive/participative style of leadership in order to achieve the best result for the organisation.

\section{Conclusions}

The study outlined in this article was an exploratory study regarding the interpretation of the concepts of "businessperson characteristics" by SME directors and answers the question: In which manner is the concept, "businessperson characteristics" (commitment/communication/leadership), interpreted and utilised by the businessperson/director? The results of the study are mostly related to family business because the business culture in the Netherlands in SME sector is most represented by family culture/culture of family business (Koning, 2013; Ouchi, 1979).

The commitment/involvement by SME directors is represented by the themes of emotional commitment, visibility, financial bond, and personality traits. The distribution patterns of the participants revealed a dominant pattern in three types of commitment elements, i.e., emotional commitment, personality traits, and a financial bond with the company. The commitment by SME directors in the Netherlands is represented by themes of: 
- Affective commitment (the emotional commitment: enjoyable, happiness in the company, like to work here);

- Continuance commitment (need as salary, bonus, profit, work experience, health, seniority and maturity, dominance).

in a three-component conceptualization of organizational commitment (Allen \& Meyer, 1991).

The communication by SME directors is represented by themes of empathy, type of information, reaction and personality of the communication. The distribution patterns of the participants (directors of SME's/family businesses) in communication elements revealed a dominant pattern in two main elements: Empathy, the listening and understanding of another person is higher represented by female respondents; personality of the director in communication is higher represented by male respondents. In the definition of Garcia represent the communication of female leader "an act of empathy directed to the employees" and the communication of male leader is "the act of own charismatic personality directed toward the own employees" in expectation of adequate response.

The leadership by SME directors is represented by themes of hierarchical, delegational, participative, and closed leadership. The distribution patterns of the participants revealed a dominant pattern in two types of leadership style, i.e., authoritarian and communicative, a flat, accessible manner of leadership and the theory of the IL Style, as a representation different styles for different situations (Missioura, 2013b).

These three concepts (commitment, communication, and leadership) determine the influence on the behaviour and activities in the practice of SME companies in the Netherlands.

The preference of the two concepts for "businessperson characteristics" by SME directors, namely, leadership and involvement/commitment shows the differences in the practise of the companies. A possible general conclusion is that the spheres of interest of SME directors: They are to close to the practice to be able to be successfully applied. The purpose of this study was not to identify if this explanation is most plausible.

The next study - survey (300 participants, the subject of another paper) - should approve the results of this explanation and discussed choice of SME directors in the Netherlands (subject of this paper) and the reliability of conceptual model (see Figure 4).

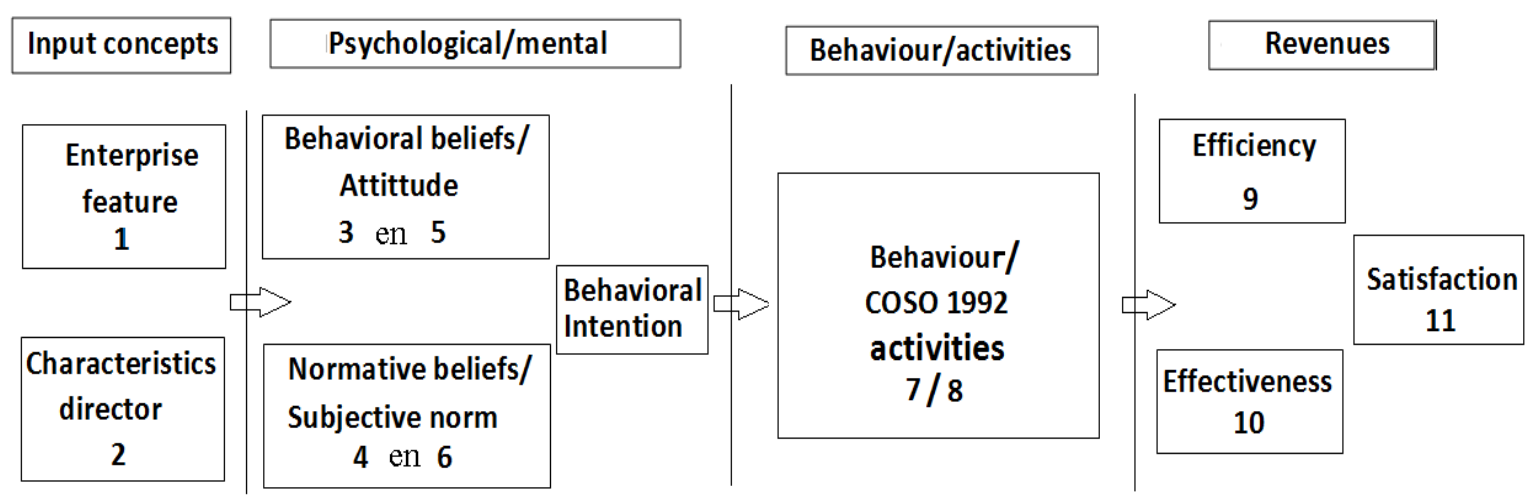

Figure 4. The result conceptual model for questionnaire.

\section{Limits of the Study}

This study was undertaken among a limited group of (19) SME directors and the selection of respondents was non-random. There is therefore some doubt concerning the representativeness of the study. Furthermore, the sample is limited in size to be able to make (statistically-reliable) statements on the entire population. The 
study is exploratory in character. The only point of investigation was - the choice of SME directors. No attempt was made to explain any discrepancies in priorities. There may a response bias, is the respondents probably wanted to make a good impression, as a result of which a discrepancy could occur between the answers given and their activities in practice or in the studies undertaken.

\section{Suggestions for Further Study}

In a further study, the possible explanations for the most notable results could be further assessed, in addition to which it would be interesting to continue this study on a larger scale (already finished - survey), to make it possible to be able to draw statistically-reliable conclusions and the most plausible explanation of the interpretation of the concepts of communication, commitment, and leadership and relationship among the concepts.

\section{References}

Al-bahussin, S. A., \& El-garaihy, W. H. (2013). The impact of human resource management practices, organisational culture, organisational innovation and knowledge management on organisational performance in large Saudi organisations: Structural equation modeling with conceptual framework. International Journal of Business \& Management, 8(22), 1-19.

Allen, N. J., \& Meijer, J. P. (1991). A three-component conceptualization of organizational commitment. Human Resourse Management Review, 1, 61-89.

Allen, N. J., \& Meijer, J. P. (1996). Affective, continuance, and normative commitment tot the organization: An examination of construct validity. Journal of Vocational Behaviour, 49, 252-276.

Allen, N. J., \& Meijer, J. P. (2001). A three-component conceptualization of organizational commitment. Human Resource Management Review, 1(1), 61-89.

Bakker-Pieper, A., \& Vries, E. (2013). The incremental validity of communication styles over personality traits for leader outcomes. Human Performance, 26(1), 1-19.

Biswas, S. (2011). Commitment, involvement, and satisfaction as predictors of employee performance. South Asian Journal of Management, 18(2), 92-107.

Buchanan, B. (1974). Building organizational commitment: The socialization of managers work organizations. Administrative Science Quarterly, 19, 533-546.

Burns, J. M. (1978). Leadership. New York: Harper \& Row.

Caligiuri, P., \& Tarique, I. (2009). Predicting effectiveness in global leadership activities. Journal of World business, 44, $336-346$.

Cardona, P. (2000). Transcendental leadership. Leadership and Organization Development Journal, 21(4), 201-206.

Carmelin, A. (2013). Leadership, creative problem-solving capacity, and creative performance: The importance of knowledge sharing. Human Resource Management, 52(1), 95-121.

Conger, J. A. (1989). The charismatic leader: Behind the mystique of exceptional leadership. San Francisco: JosseyBass.

Conger, J. A., \& Kanungo, R. N. (1987). Toward a behavioral theory of charismatic leadership in organizational setting. Academy of Management Review, 12, 637-647.

Conger, J. A., \& Kanungo, R. N. (1988). Behavioral dimensions of charismatic leadership. In J. A. Conger, \& R. N. Kanungo (Eds.), Charismatic leadership: The elusive factor in organizational effectiveness. San Francisco: Jossey-Bass.

Conger, J. A., \& Kanungo, R. N. (1988). Charismatic leadership: The elusive factor in organizational effectiveness. San Francisco: Jossey-Bass.

Conger, J. A., \& Kanungo, R. N. (1992). Perceived behavioral attributes of charismatic leadership. Canadian Journal of Science, 24, 86-102.

Conger, J. A., \& Kanungo, R. N. (1994). Charismatic leadership in organizations: Perceived behavioral attributes and their measurement. Journal of Organizational Behavior, 15, 439-452.

Conger, J. A., Kanungo, R. N., \&Menon, S. T. (2000). Charismatic leadership and followers effect. Journal of Organizational Behavior, 21, 747-767.

Conger, J. A., Kanungo, R. N., Menon, S. T., \& Mathur, P. (2009). Measuring charisma: Dimensionality and validity of the Conger Kanungo scale of charismatic leadership. Canadian Journal of Behavioral Science, 14(3), 290-302.

COSO. (2006). The committee of sponsoring organizations of the treadway commission. Retrieved from http://www.coso.org 
Coulson-Thomas, C. (2013). "New leadership" and creating the high performance organization: Part 1. Industrial and Commercial Training, 45(1), 23-31.

Ehrhart, M. G., \& Klein, K. J. (2001). Predicting followers' preferences for charismatic leadership: The influence of follower values and personality. Leadership Quarterly, 12(2), 153-179.

Etzioni, A. (1964). Modern organizations (p. 67). Englewood Cliffs, N.J.: Pretice-Hall.

Etzioni, A. (1993). Normative-affective choices: Human relations. Washington: Sage Publications.

Felf, J., \& Schyns, B. (2006). Personality and the perception of transformational leadership: The impact of extraversion, neuroticism, personal need for structure, and occupational self-efficacy. Journal of Applied Social Psychology: Devoted to Applications of Experimental Behavioural Science Research to Problems of Society, 36, 708-739.

Fishbein \& Aijzen. (1975). Belief, attitude, intention and behaviour: An introduction to theory and research. USA: Addison-Wesley Gamigo Publishing Company.

Garcia, H. F. (2012). Leadership communications: Planning for the desired reaction. Strategy \& Leadership, 40(6), 42-45.

Goldberg, L. R. (1992). The development of markers for the big-five factor structure. Psychological Assessment, 4(1), $26-42$.

Hamm, J. (2006). The five messages leaders must manage. Harvard Business Review, 84(5), 114-123.

Haneberg, L. (2009). How leaders can optimize organizational culture. White Paper MPI Consulting.

Hoell, R. C. (2004). How employee involvement affects union commitment. Journal of Labor Research, 25, 267-277.

House, R. J. (1977). A 1976 theory of charismatic leadership. In J. G. Hunt, \& L. L. Larson (Eds.), Leadership: The cutting edge. Carbondale. IL: Southern Illinois University Press.

Kibeom, L., Allen, N. J., \& Meijer, J. P. (2001). A three-component conceptualization of organizational commitment: An application to South Korea. An International Review, 1, 596-614.

Koning, F. (2013). The human side of administrative organisation (De menselijke kant van BIV). Breukelen, The Netherlands: Nyenrode Business University.

Lagrosen, Y., Bäckström, I., \& Wiklund, H. (2012). Approach for measuring health-related quality management. The TQM Journal, 24(1), 59-71.

March, J. G., \& Mannari, H. (1977). Organizational commitment and turnover: A preditive study. Administrative Science Quarterly, 22, 57-75.

Martin, S., Liao, H., \& Campbell, E. M. (2013). Directive versus empowering leadership: A field experiment comparing impacts on task proficiency and proactivity. Academy of Management Journal, 56(5), 1372-1395.

Missioura, O. V. (2013a). Inclusive leadership in the small to medium-sized enterprise sector. Global Journal of Strategies \& Governance, ISSN 1923-6042, vol XX, p. 1-14.

Missioura, O. V. (2013b). Leadership and internal control in SME sector (A qualitative analysis of external validity practices by small to medium enterprise sector directors). Proceedings from 8th Annual London Business Research Conference, London.

Moss Simon, A., \& Ngu, S. (2006). The relationship between personality and leadership preferences. Current Research in Social Psychology, 11(6), 70-91.

Mowday, R. T., Porter, L. W., \& Steers, R. M. (1982). Employee organizational linkages. New York: Academy Press.

Muijen, J. J. (2003). Leadership development: The use of paradoxes (Leiderschapsontwikkeling: het hanteren van paradoxen). Universiteit Nyenrode: Breukelen.

Ouchi, W. G. (1979). A conceptual framework for the design of organizational control mechanisms. Management Science, 25(9), 833-848.

Rego, A., Sousa, F., Marques, C., \& Pina e Cunha, M. (2014). Hope and positive affect mediating the Authentiek leadership and creativity relationship. Journal of Business Research, 67(2), 200-210.

Remund, D. (2011). Asking the right questions, involving the right people. Journal of Leadership Studies, 5(3), 40-52.

Sam, M. F. M. (2012). Owner-managers of SMEs in it sector: Leadership and company performance. International Journal of Business \& Social Science, 3(14), 195-205.

Sinar, E. (2013). Is the millennial generation ready to lead?. Training, 50(4), 20.

Soumendu, B. (2011), Commitment, involvement, and satisfaction as predictorsof employee performance. South Asian Journal of Management, 18(2), 92-107.

Tse, H. M., \& Chiu, W. C. K. (2014). Transformational leadership and job performance: A social identity perspective. Journal of Business Research, 67(1), 2827-2835.

Uçanok, B., \& Karabatı, S. (2013). The effects of values, work centrality, and organizational commitment on organizational citizenship behaviors: Evidence from Turkish SMEs. Human Resource Development Quarterly, 24(1), 89-129. 
van der Valk, H. M. H. A. (1950). Elementary textbook of economics (Voortgezet elementair leerboek der economie). Arnhem: G.W. Van der Wiel \& Co.

Venus, M., Stam, D., \& Van Knippenberg, D. (2013). Leader emotion as a catalyst of effective leader communication of visions, value-laden messages, and goals. Organizational Behavior \& Human Decision Processes, 122(1), 53-68.

Wallage, E., De Chernatony, L., \& Buil, I. (2013a). Building bank brands: How leadership behavior influences employee commitment. Journal of Business Research, 66(2), 165-171.

Wallage, E., De Chernatony, L., \& Buil, I. (2013b). Building bank brands: How leadership behavior influences employee commitment. Journal of Business Research, 66(2), 165-171.

Weber, M. (1974). The theory of social and economic organizations. NewYork: Free Press.

Wiener, Y. (1982). Commitment in organizations: A normative view. Academy of Management Review, 7, 418-428. 